\title{
FIELD PERFORMANCE OF \\ CAVITATION EROSION RESISTANT ALLOY \\ ON PUMPED-STORAGE HYDROTURBINE
}

TENNESSEE VALLEY AUTHORITY

RACCOON MOUNTAIN UNIT-3

OCTOBER 1992

\author{
Prepared by \\ TENNESSEE VALLEY ADTHORITY \\ RESOURCE GROUP \\ RESEARCH AND DEVELOPMENT \\ GENERATIONS PROJECTS DEPARTMENT
}

PRINCIPAI INVESTIGATORS

O. F. Karr, Mechanical Engineer Generation Projects Department - Research and Development

J. B. Brooks, Metallurgist Generation Projects Department Research and Development

P. A. March, Senior Mechanical Engineer Engineering Laboratory, Norris, TN

J. M. Epps, Plant Manager

Raccoon Mountain Pumped-Storage Plant 


\section{DISCLAIMER}

This report was prepared as an account of work sponsored by an agency of the United States Government. Neither the United States Government nor any agency thereof, nor any. of their employees, make any warranty, express or implied, or assumes any legal liability or responsibility for the accuracy, completeness, or usefulness of any information, apparatus, product, or process disclosed, or represents that its use would not infringe privately owned rights. Reference herein to any specific commercial product, process, or service by trade name, trademark, manufacturer, or otherwise does not necessarily constitute or imply its endorsement, recommendation, or favoring by the United States Government or any agency thereof. The views and opinions of authors expressed herein do not necessarily state or reflect those of the United States Government or any agency thereof. 


\section{DISCLAIMER}

Portions of this document may be illegible in electronic image products. Images are produced from the best available original document. 


\section{ACKNOWLEDGMENTS}

Many individuals inside and outside the Tennessee Valley Authority (TVA) contributed to the development, testing, demonstration, and commercial use of the stoody Hydroloy HQ913 mig wire for repairing cavitation damaged areas in TVA hydroturbines. Good cooperation between the people listed below permitted the earliest possible commercial use of HQ913 for repairing turbines. TVA believes this new material will save a considerable amount of money due to decreases in maintenance cost, better hydro unit availability, and better turbine efficiencies.

The people listed below were involved in the introduction of HQ913 material for the repair of hydroturbines in TVA hydro plants: Raynald Simoneau (Research Metallurgist, Hydro-Quebec Research) was the lead Metallurgist in developing IRECA, which is the same material as Stoody Hydroloy HQ913; Jim Weedman and Larry Schultz (Thermadyne stoody Co.) were instrumental in developing the stoody Hydroloy HQ913 MIG welding wire from the IRECA composition; Vern sutter (American Welding Institute) developed welding procedure specifications for HQ913 MIG wire; P. A. March (Senior Mechanical Engineer at the TVA Engineering Laboratory in Norris, $T N$ ) and Gordon Bohannan (Technician) were instrumental in performing cavitation erosion testing on IRECA and other cavitation erosion resistant materials; Rebecca Goins and her staff at the TVA Central Laboratories provided metallurgical laboratory services; $E$. $D$. Daugherty, C. M. Huang, J. D. Fourroux, and T. W. Newberry provided Research and Development (R\&D) management support; orval Karr (R\&D Mechanical Engineer) and John Brooks (R\&D Metallurgist) provided coordination inside and outside TVA in testing and demonstrating HQ913 in the TVA Hydroturbines; Mike Thompson, Jeffery Jones, John Andrews, and L. L. Curvin (central staff hydro maintenance) provided coordination for installation and field testing; Frank E. Adkins (former Manager of Hydro operations) and Enrique Martinez (Vice President of Hydro operations) and their staffs provided support for field testing; Gilbert F. Lindsay (former Manager of the Raccoon Mountain Plant) and Joe M. Epps, (Manager of the Raccoon Mountain Plant) and their staffs (including W. A. Dintsch and Randy Cox) provided support for field testing and demonstrating HQ913 in the Raccoon Mountain hydroturbines. 


\section{FOREWORD}

Cavitation erosion has been a maintenance problem in hydro plants throughout the world since these plants began operating. TVA plants were no exception. In 1985 Research and Development (R\&D), and Fossil \& Hydro Power (F\&H PR) began a search for materials that were more resistant to cavitation erosion than the materials being used. Previous to 1986 the Tennessee Valley Authority, the U.S. Army Corps of Engineers, and other utilities with hydro power plants were using 7018, 309 stainless steel, and 308 stainless steel stick electrodes to repair cavitation damaged areas in hydroturbines. In some cases stellite 21 and other expensive materials were used in areas where there was severe cavitation erosion.

By late 1986 R\&D and F\&H PR had installed test coatings and weld overlays of cavitation resistant materials in several hydro plants. The TVA Engineering Laboratory at Norris, TN had identified several cavitation resistant materials, including the IRECA material that was being developed by Hydro-quebec specifically for repairing cavitation damaged areas in hydroturbines. Cavitation erosion tests at the TVA Engineering Laboratory and the Hydro-Quebec Research facility had indicated the IRECA test material was several times more resistant to cavitation erosion than the materials being used for cavitation repair.

In early 1987 the stoody Company made small quantities of IRECA mig wire for tests and evaluation. By late 1987 TVA had installed test patches of IRECA weld overlays in several hydroturbines. By mid1988 TVA was satisfied with the weldability and performance of the IRECA alloy, which was marketed under the names of stoody Deloro HQI and stoody Hydroloy HQ913. TVA began using the MIG wire commercially for repairing cavitation eroded areas in the hydroturbines at the Raccoon Mountain-Pumped storage Plant (RPS) and for repairing areas in other hydroturbines that experience severe cavitation erosion.

The Authors believe the Stoody Hydroloy HQ913 material has proven itself cost effective in reducing the amount of cavitation erosion taking place in hydroturbines. Less cavitation erosion reduces maintenance cost, increases plant availability, and permits hydroturbines to run at higher efficiencies. 


\section{CONTENTS}

ITEM

PAGE

Introduction

1

Results

2

Recommendations

2

Sketch of cavitation repair areas in hydroturbine

3

Sketch showing details of installing HQ913

weld overlay in deep cavitated areas

4

Photographs of cavitation damage to blades \& crown

$5-12$

Photographs comparing the performance of 308 SS,

309 SS, and HQ913 weld overlays

$13-14$ 


\title{
FIELD PERFORMANCE OF \\ CAVITATION EROSION RESISTANT ALLOY \\ ON PUMPED-STORAGE HYDROTURBINE
}

\author{
TENNESSEE VALLEY AUTHORITY \\ RACCOON MOUNTAIN UNIT-3 \\ OCTOBER 1992
}

\section{INTRODUCTION}

The TVA Raccoon Mountain Plant is a four unit pumped-storage plant located on the Tennessee River, Nickajack Reservoir, in Marion County, Tennessee, six miles $(3.7 \mathrm{~km})$ west of Chattanooga, Tennessee. The four units went into commercial operation between January 31, 1978 and August 31, 1979. Each unit has a generating rating of 392 MW at a $1020 \mathrm{ft}$ head (310.9 meters). Each turbine is a reversible Francis type, with vertical shaft, manufactured by Allis-Chalmers (now Voith Hydro, Inc.). The runner diameter is 16 ft 7 inches (5.05 meters). The runner material is ASTM A296-CA6NM.

This report describes results of a 27 month exposure in a fuIl scale demonstration of Stoody Hydroloy HQ913 (HQ913) weld overlay installed on the Raccoon Mountain Unit 3 hydroturbine runner. This installation was the logical extension of laboratory work and field testing completed prior to 1989. Laboratory tests had shown HQ913 to be several times more resistant to cavitation erosion than 309 , 308 , and 309L stainless steels previously used for repairing cavitation damage. In addition, field test patches installed at Raccoon Mountain had demonstrated the superior cavitation resistance of HQ913. The runners at Raccoon Mountain experience excessive cavitation damage ranging from mild to severe. Therefore, it was decided in 1988 to use HQ913 to repair all cavitation damaged areas of the runners in all units at their next scheduled cavitation repair outages. All the cavitated areas in the unit 3 runner were arc-air gouged out during the 1990 spring outage and repaired with HQ913 weld overlay. Figure 1 shows the principal cavitation erosion areas where HQ913 weld overlay was used. Figures 2 and 3 show details for weld repairs made on deep cavitation eroded areas.

Repairs were completed and the unit was placed in service on July 5, 1990. It was taken out of service for a scheduled maintenance inspection and outage on October 5, 1992. Between July 5, 1990 and October 5, 1992 it generated electricity 2,300 hours and pumped water 2,571 hours (a total operating time of 4,871 hours). 


\section{RESULTS}

The use of HQ913 weld overlay for repairing the cavitation eroded areas of the runner was beneficial in reducing the area and depth of cavitation erosion on the blades and in the crown. When 308 and 309 Stainless steel was used to repair the hydroturbine, it was common to have 1 inch $(2.54 \mathrm{~cm})$ deep cavitation erosion in the crown after operating the unit for one year. Twenty seven (27) months after repairing the runner with HQ913 the cavitation erosion was no more than $1 / 2$ inch $(1.27 \mathrm{~cm})$ deep in the crown. Figures 4 through 27 shows how the runner looked in April 1992 after operating for 27 months. This is the area that experiences the most severe cavitation erosion. Figures 28 through 31 show that the HQ913 weld overlay is much more resistant to cavitation erosion than the 308 and 309 stainless steel weld overlays.

Use of HQ913 should be beneficial in reducing the amount of time, and/or frequency required to weld repair hydroturbine runners. Less repeat welding on the runners due to the use of HQ913 should reduce distortion. Less cavitation damage with the use of HQ913 should permit smoother runner surfaces in contact with high velocity water and allow the turbine to run at a higher efficiency. Maintaining the turbines at higher efficiencies in all the plants will result in significant savings to TVA.

\section{RECOMMENDATIONS}

It is recommended that TVA continue to use stoody Hydroloy HQ913 MIG welding wire for repairing cavitation damaged areas on the Raccoon Mountain hydroturbines and on other hydroturbines in areas that experience severe cavitation erosion until a better repair material becomes available.

Cavitation erosion tests performed in the TVA Engineering Laboratory at Norris, Tennessee have indicated a new MIG wire (CA-T1) being developed by Teledyne Mckay may be more resistant to cavitation erosion than the stoody Hydroloy HQ913. CA-T1 is also expected to cost less and to have increased weldability compared to HQ913 MIG wire. Two weld overlay test patches of CA-TI were installed in unit 2 on April 1, 1992 for tests and evaluation. 


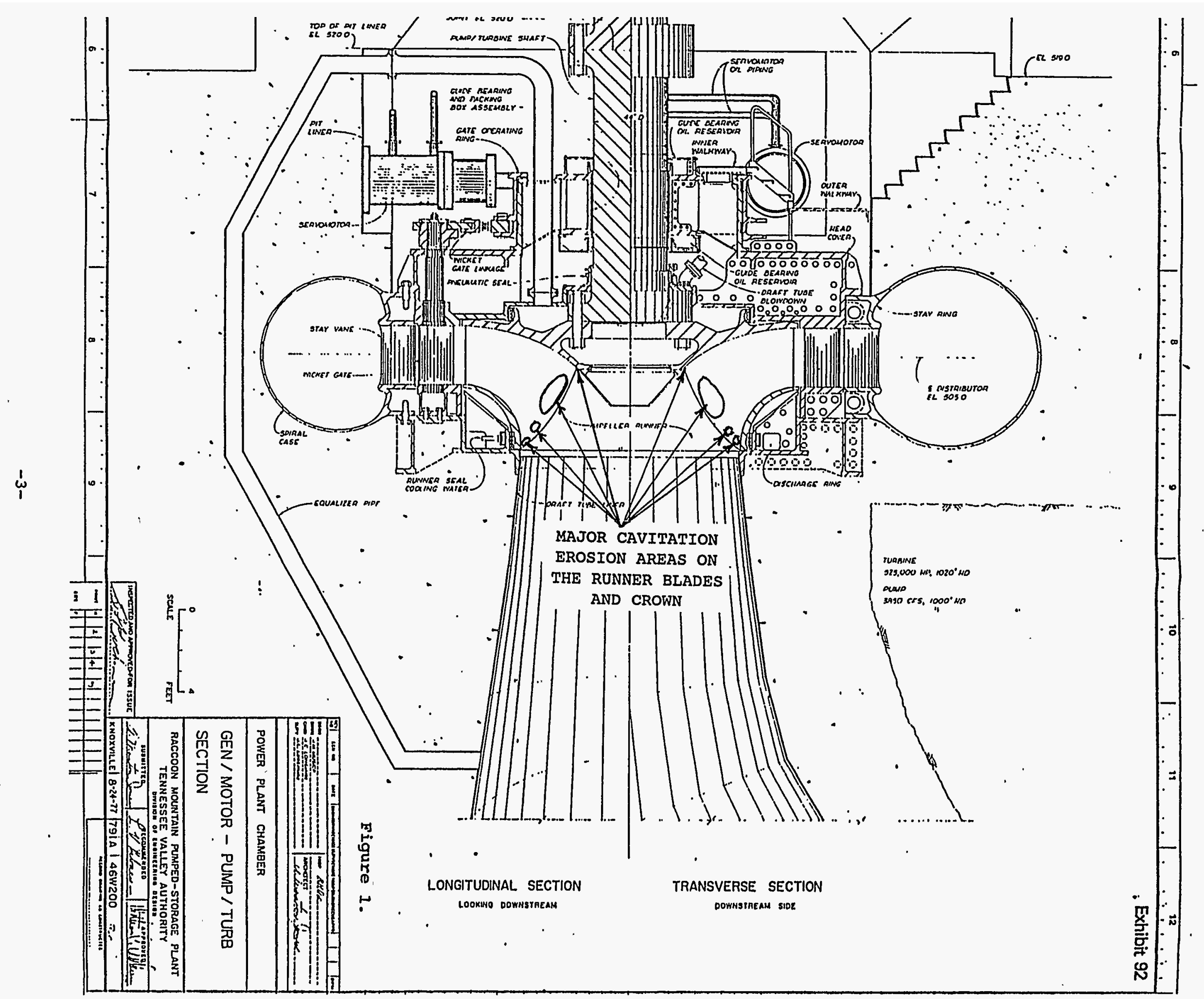




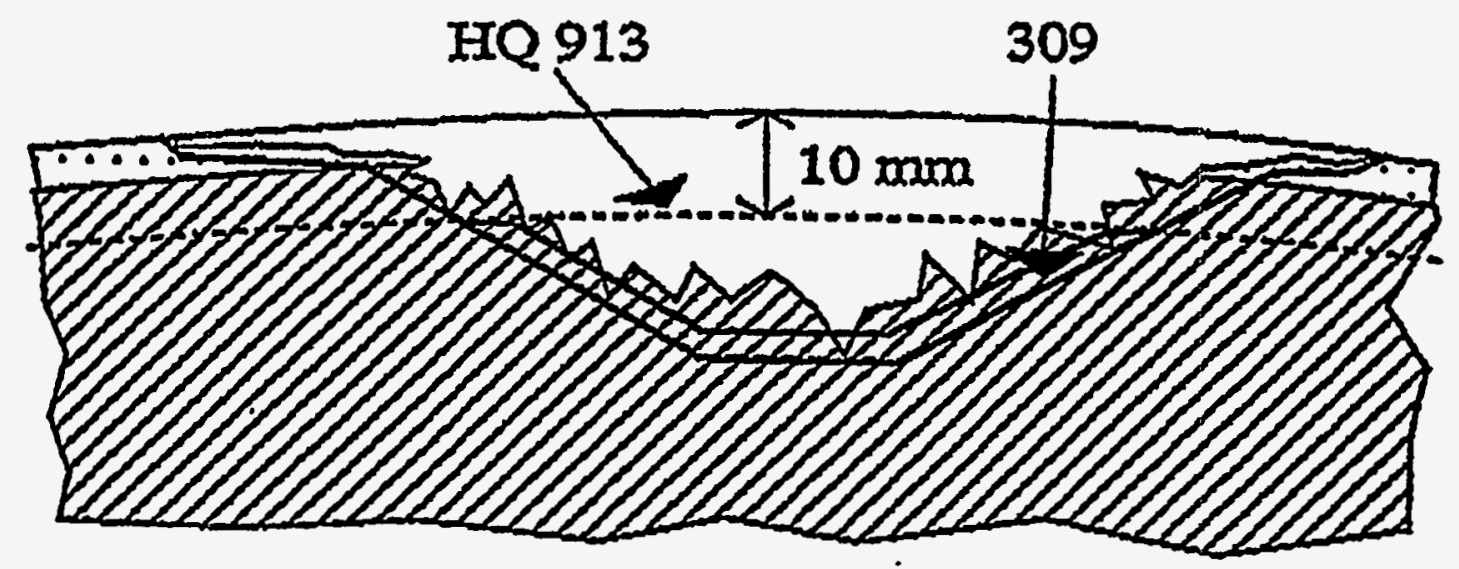

Figure 2. Cross section view shows an area that has cavitation erosion deeper than $10 \mathrm{~mm}$ as is often found in the crown areas of the hydroturbines at the Raccoon Mountain Pumped-storage Plant.

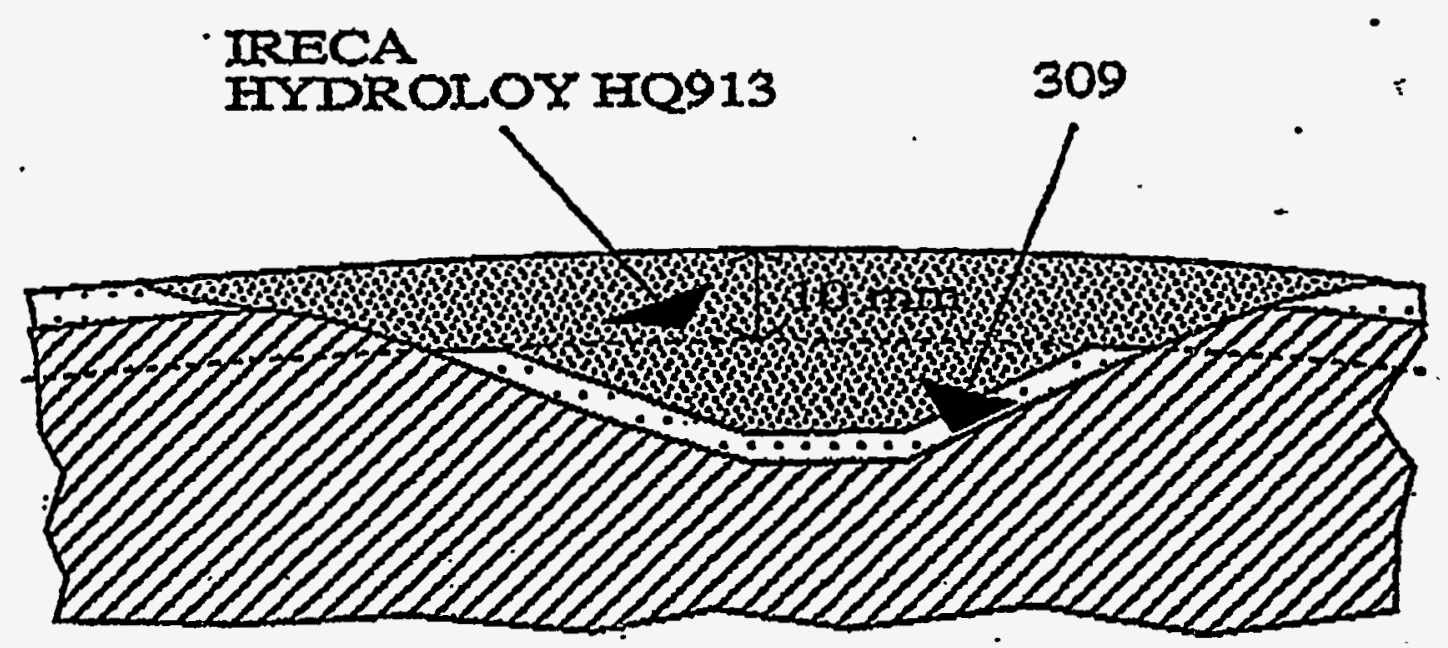

Figure 3. Cross section view of the procedure recommended by R. Simoneau of Hydro-Quebec to repair deep cavitation erosion in ASTM A296-CA6NM runners. Deep cavitation eroded areas in the runner crown of unit 3 were repaired using this procedure during the 1990 spring outage. The same procedure will be used in subsequent outages for repairing deep cavitation erosion in the crown. The Shielding gas used with the HQ913 mig wire was $98 \% \mathrm{Ar} / 2 \% \mathrm{O}_{2}$ for the $0.062 "$ (1.6 mm) Dia wire and $75 \% \mathrm{Ar} / 25 \% \mathrm{CO}_{2}$ for the $0.045^{\prime \prime}(1.2 \mathrm{~mm})$ Dia wire.

Cavitated areas on the blades were repaired by arc-air gouging out the cavitated areas to about $3 / 8 "(9.5 \mathrm{~mm})$ deep and then welding back two layers of HQ913 weld overlay. The weld overlay was then ground smooth and to the proper contour. 


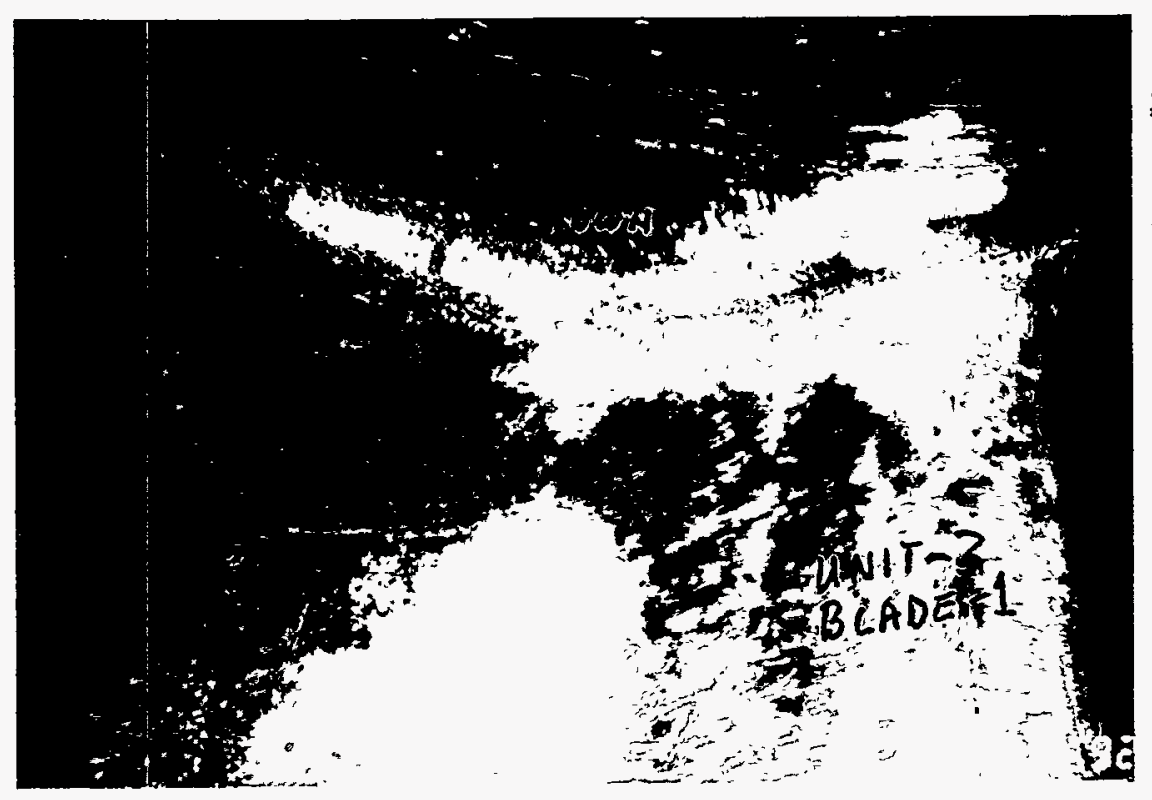

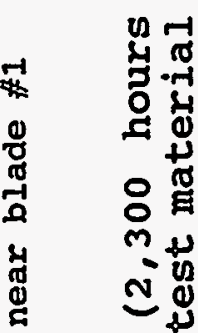

ร 约

의닫

ชั כี

- 1

$\rightarrow$ g

요

$\infty \pi$

in

प्山 뱅

$-10$

T)

$+0$
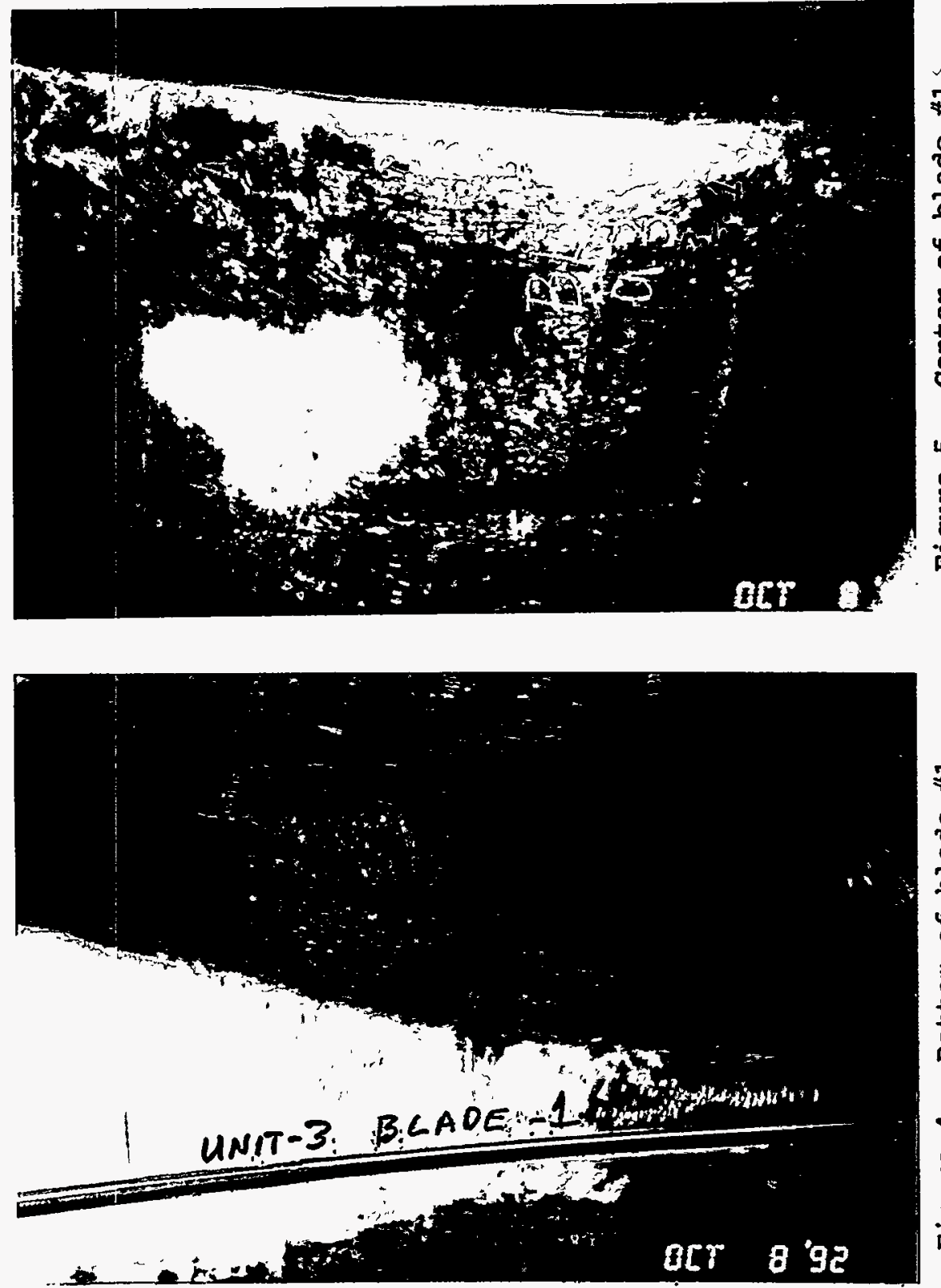

+ r

零

o

용

+

단

40

\%

걱

这占

4

3

댕

它

(5)

요

ᄃ号

ขึ

넉

웅워

4 대

c 숭 웅

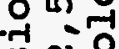

in $N$

뭉

崖运

동 울중

.

$+4$

+ to

엉 ชั 


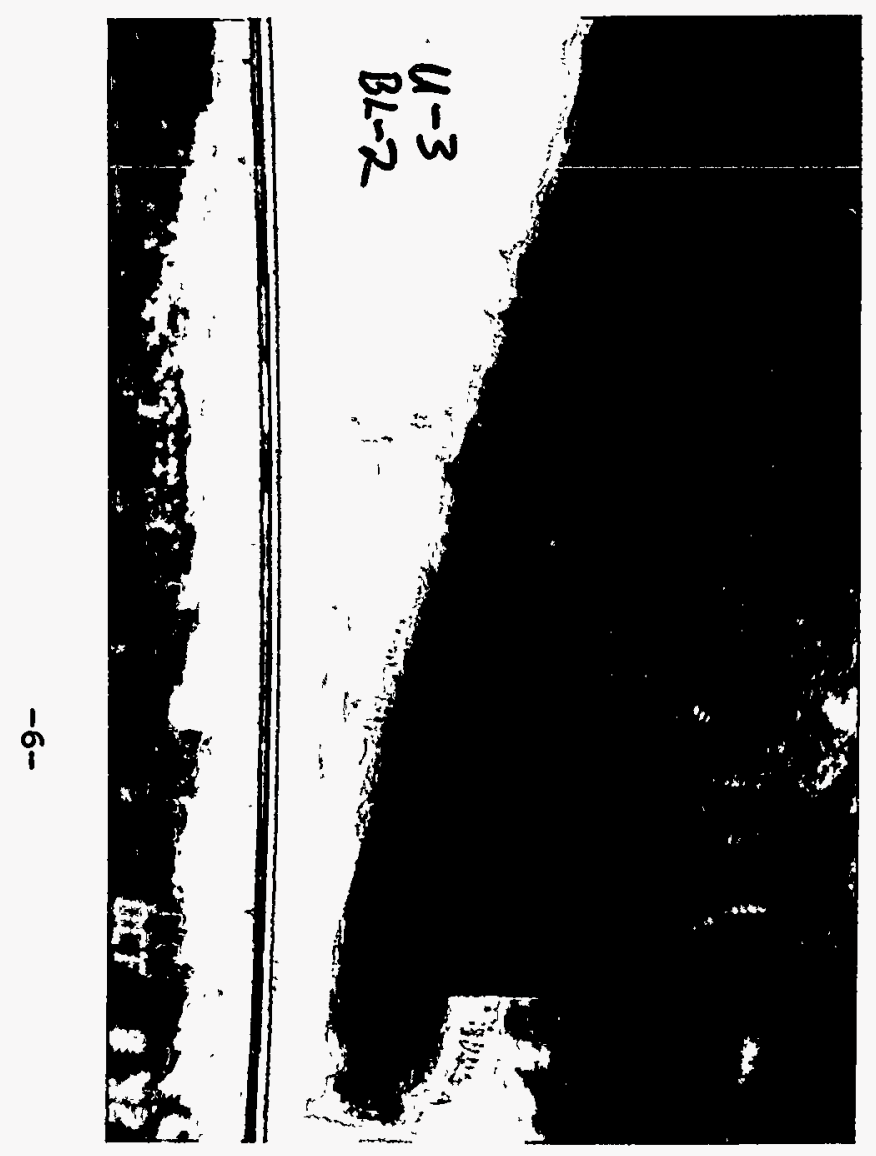

Figure 7. Bottom of blade $\$ 2$

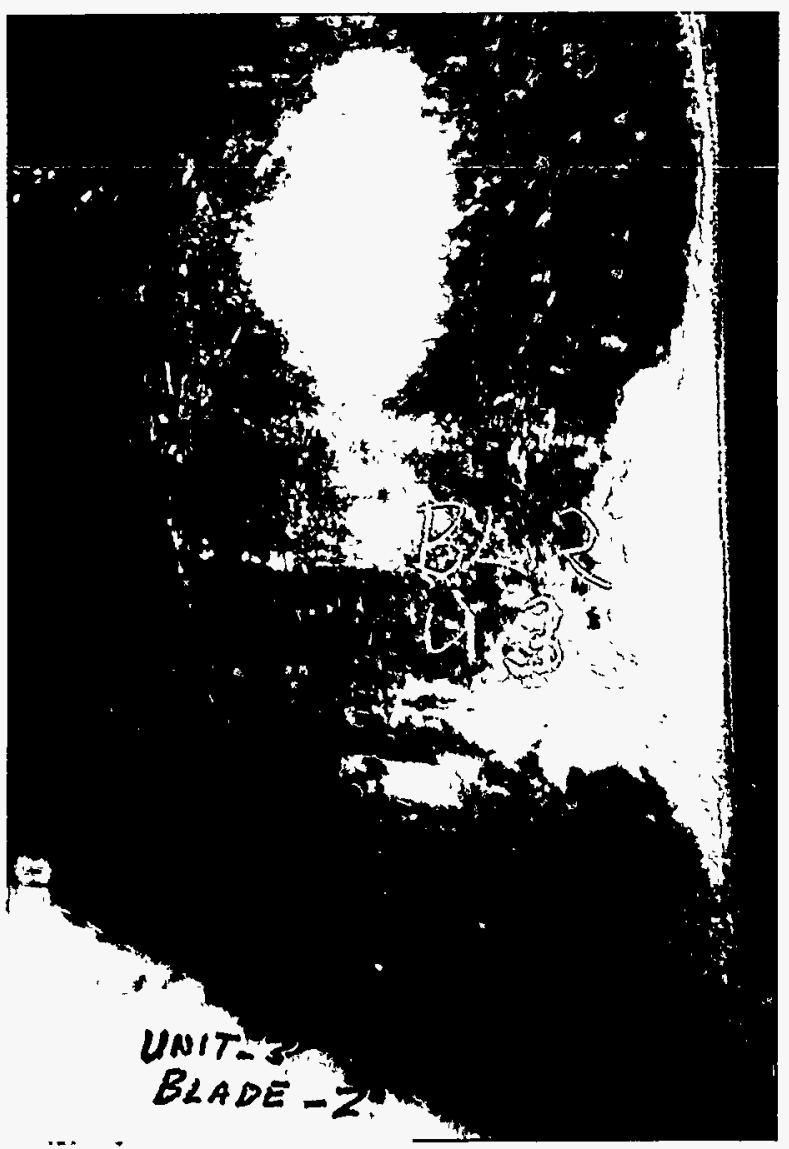

Figure 8. Center of blade \#2

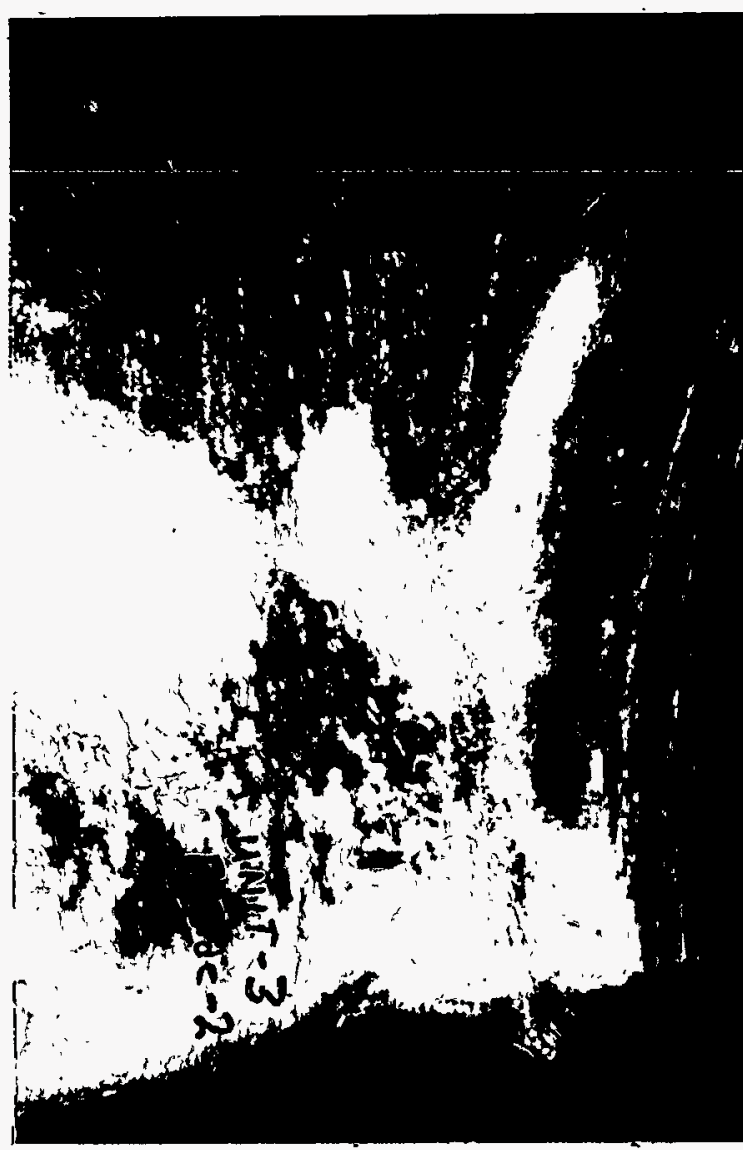

Figure 9. Crown near blade \#2

Cavitation erosion found on blade \#2 after operating a total of 4,871 hours (2,300 hours Generating and 2,571 hours Pumping) between July 5, 1990, and October 5, 1992. The test material was Stoody Hydroloy HQ913. 


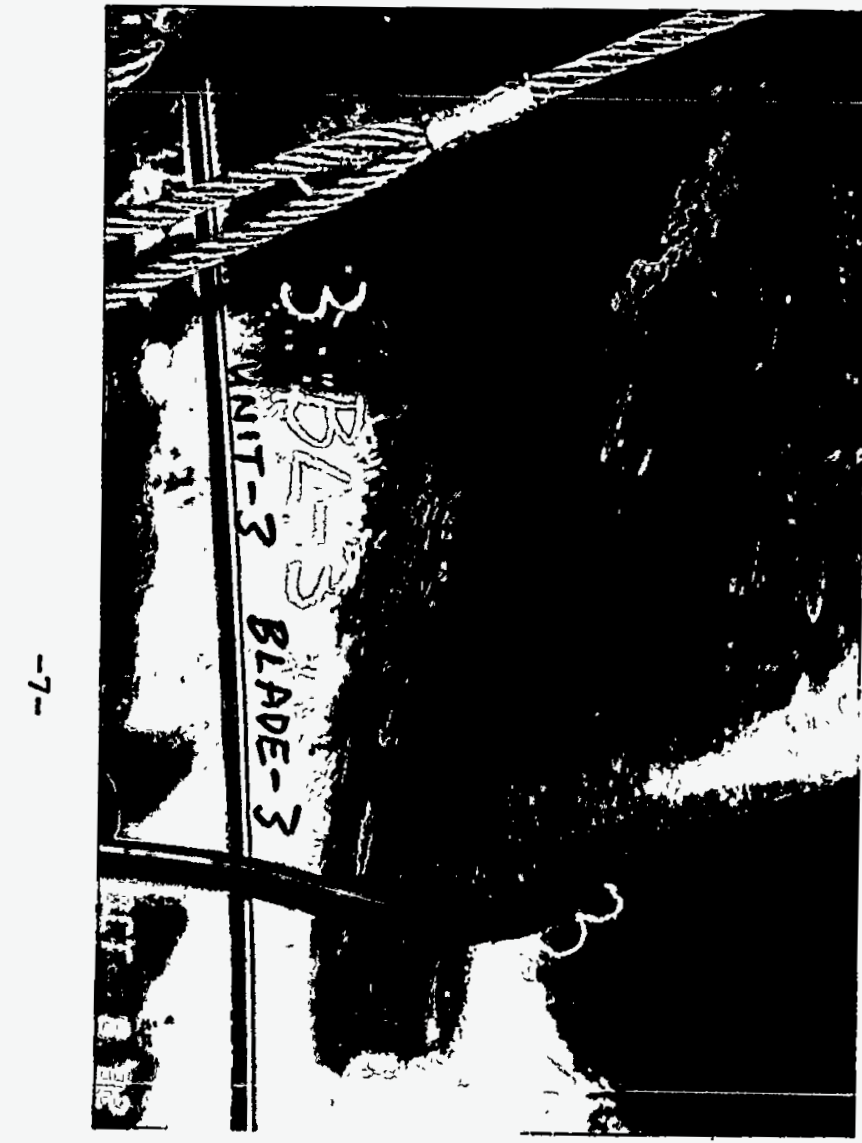

Figure 10. Bottom of blade \#3

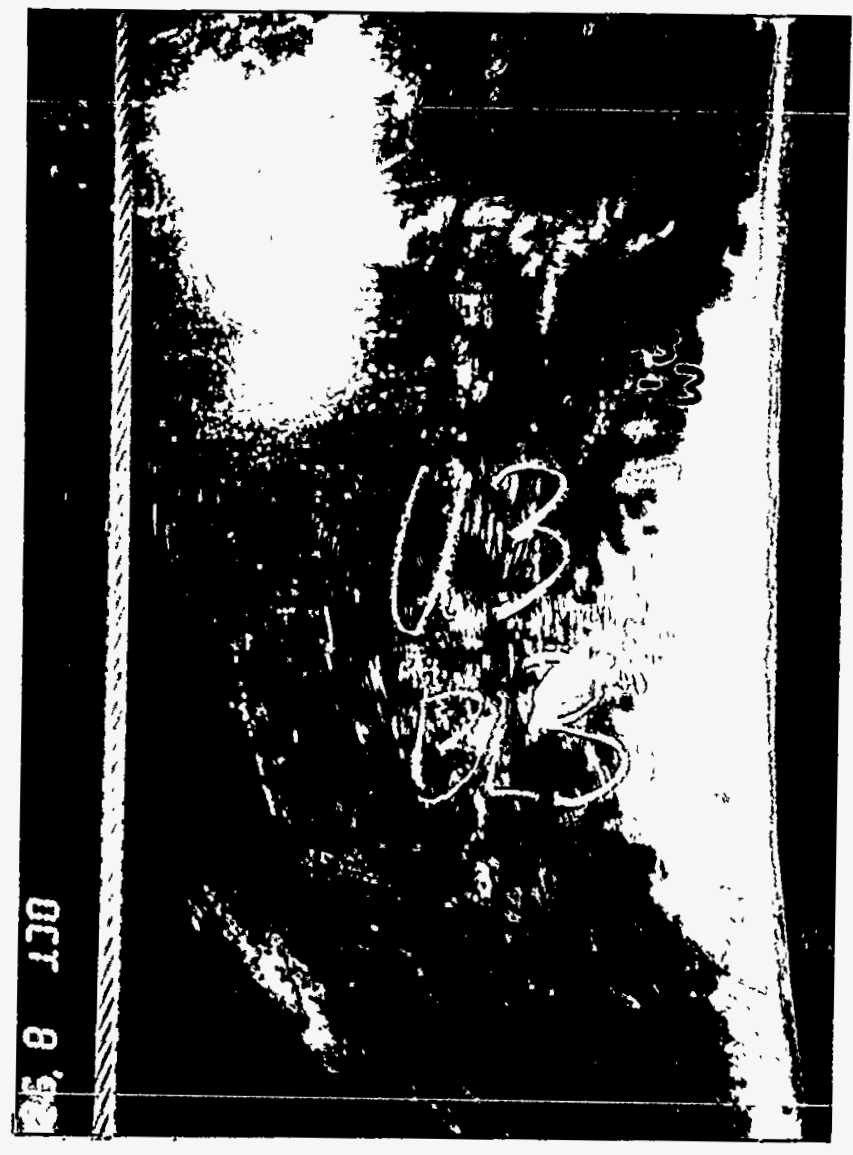

Figure 11. Center of blade \#3

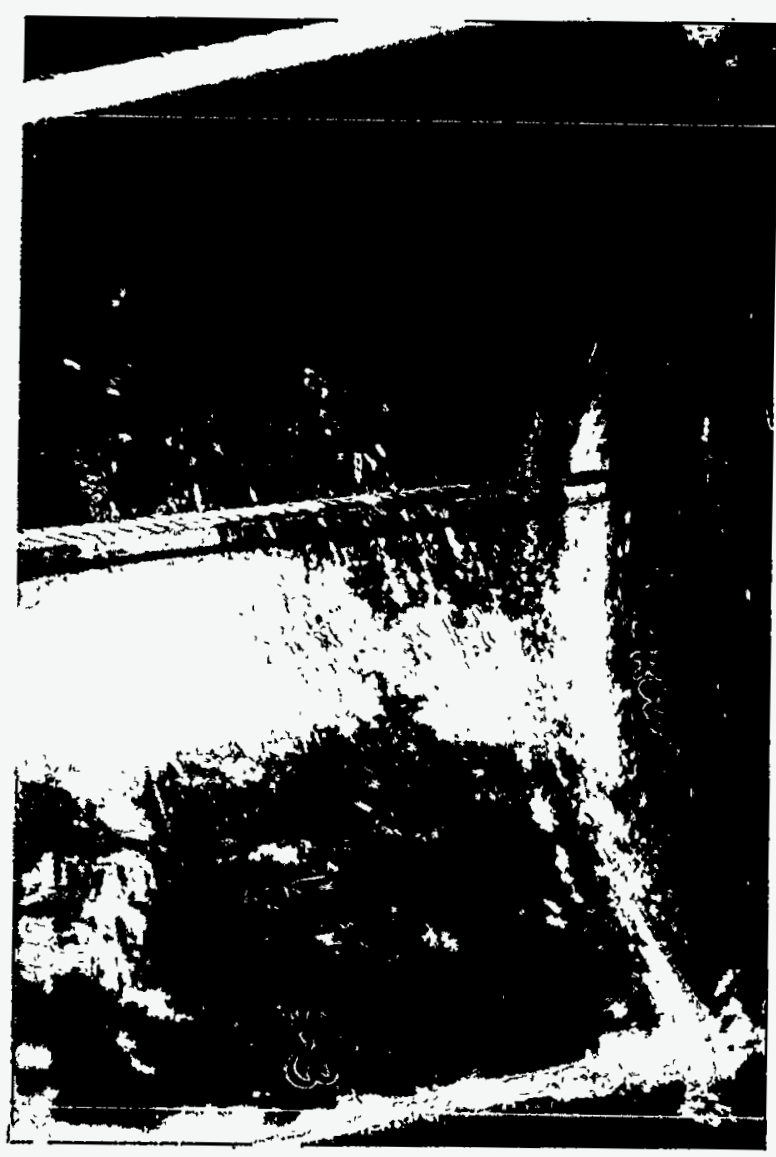

Figure 12. Crown near blade $\# 3$

Cavitation erosion found on blade \#3 after operating a total of 4,871 hours (2,300 hours Generating and 2,571 hours Pumping) between July 5, 1990, and October 5, 1992. The test material was Stoody Hydroloy HQ913. 


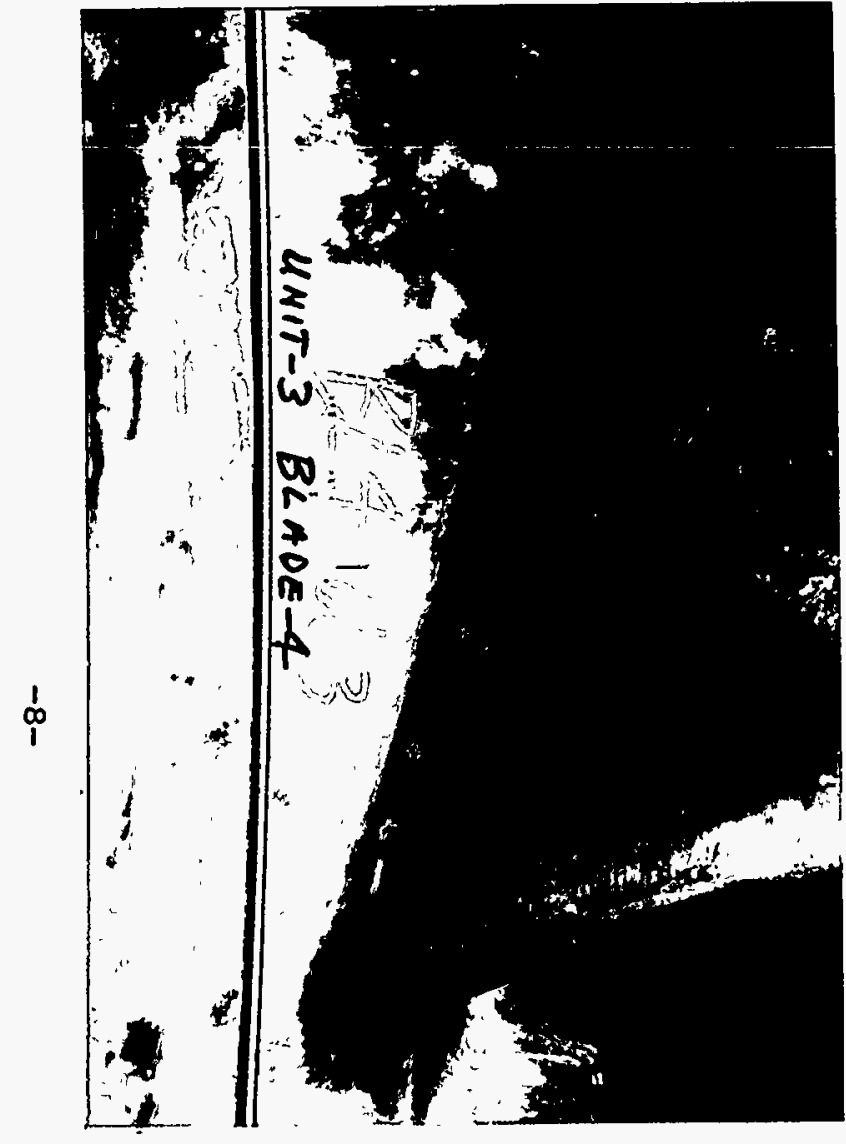

Figure 13. Bottom of blade \#4

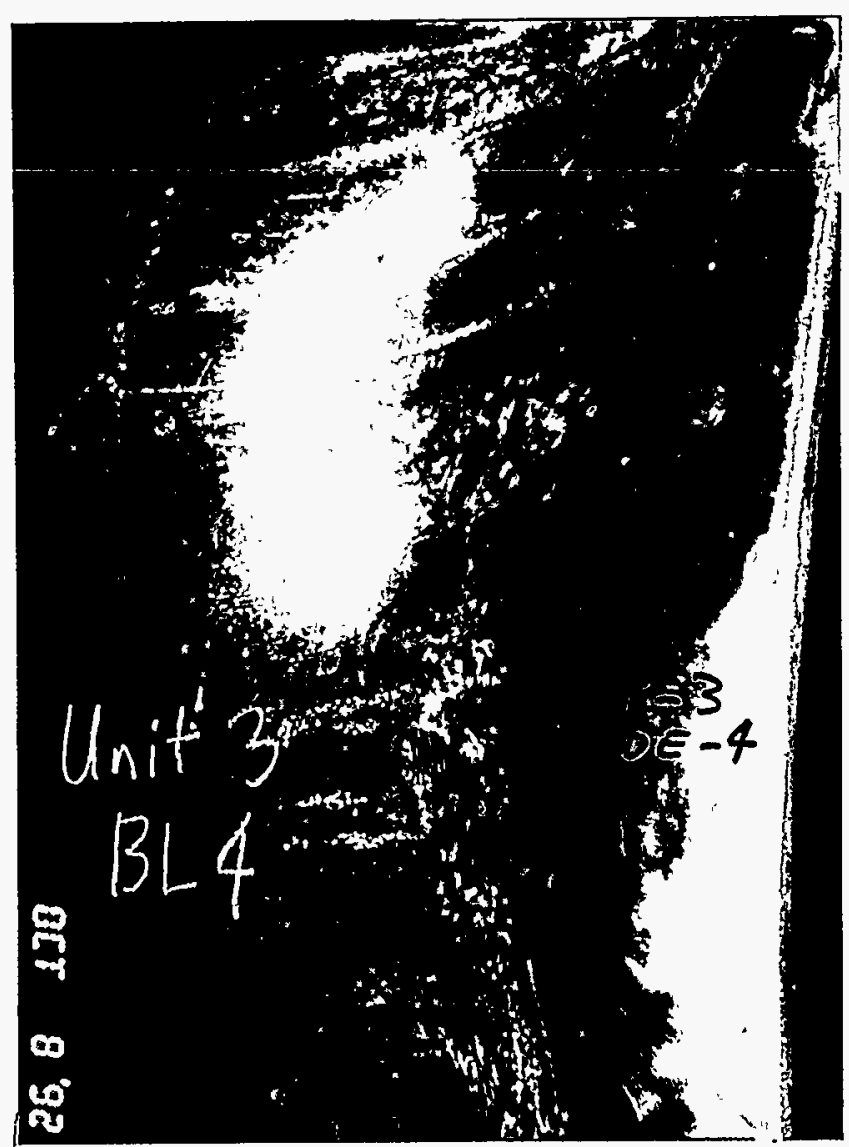

Figure 14. Center of blade $\# 4$

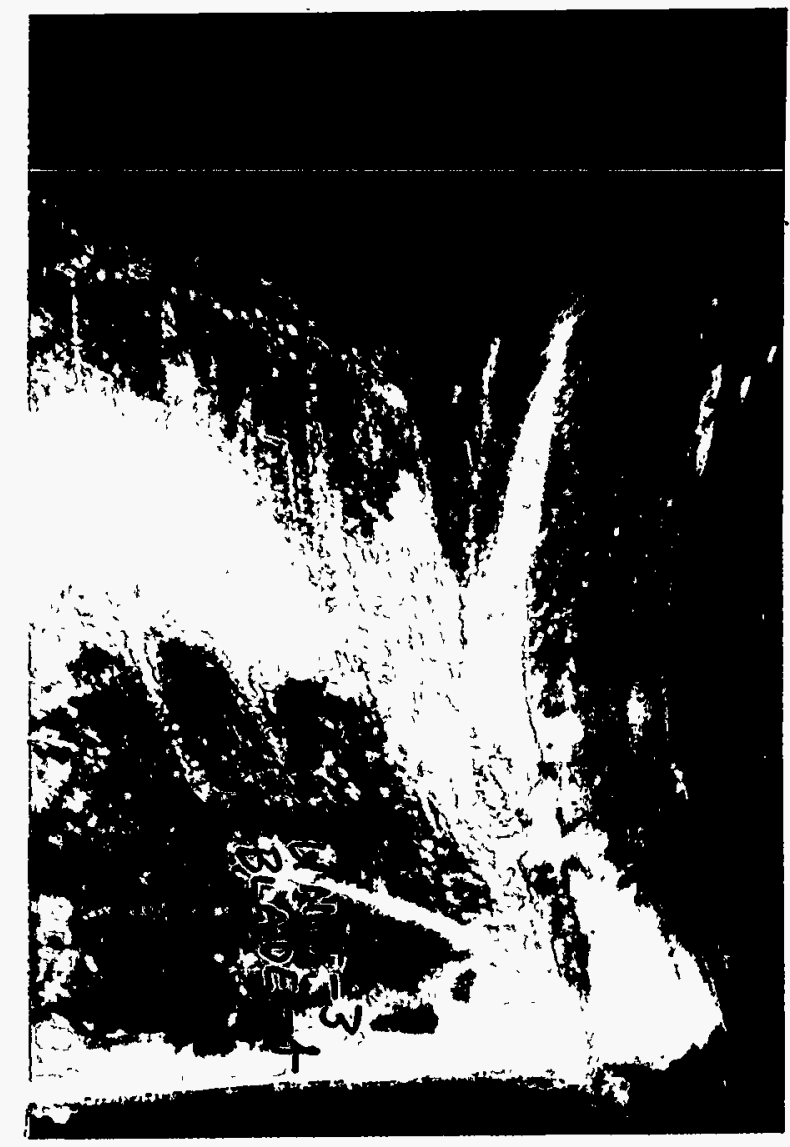

Figure 15. Crown near blade \#4

Cavitation erosion found on blade $\# 4$ after operating a total of 4,871 hours (2,300 hours Generating and 2,571 hours Pumping) between July 5, 1990, and October 5, 1992. The test material was stoody Hydroloy HQ913. 


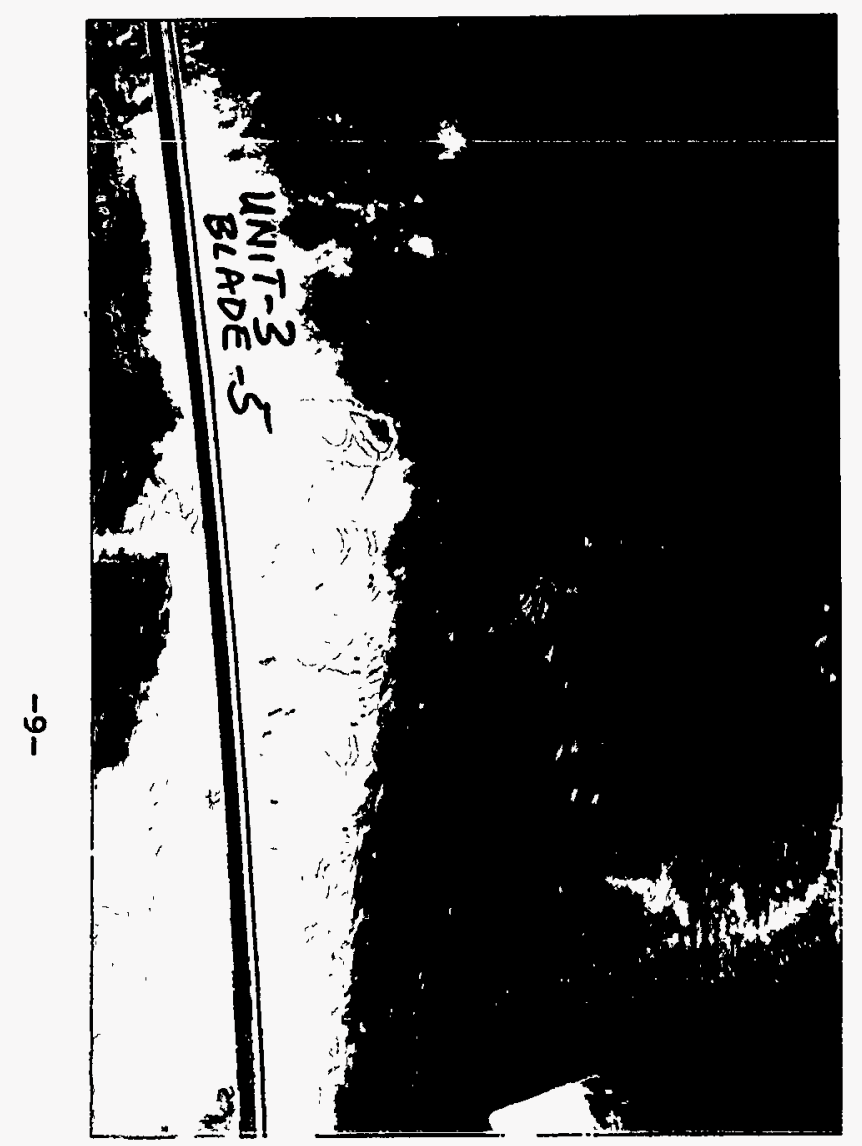

Figure 16. Bottom of blade \#5

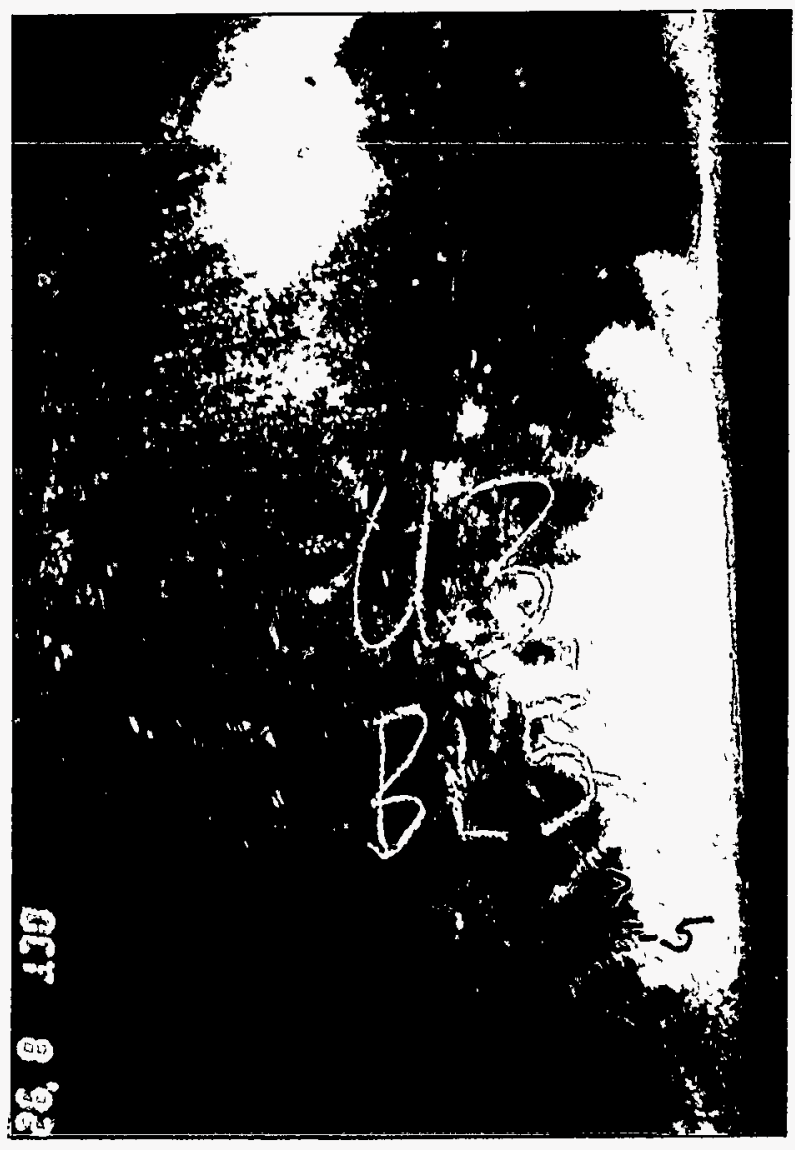

Figure 17. Center of blade \#5

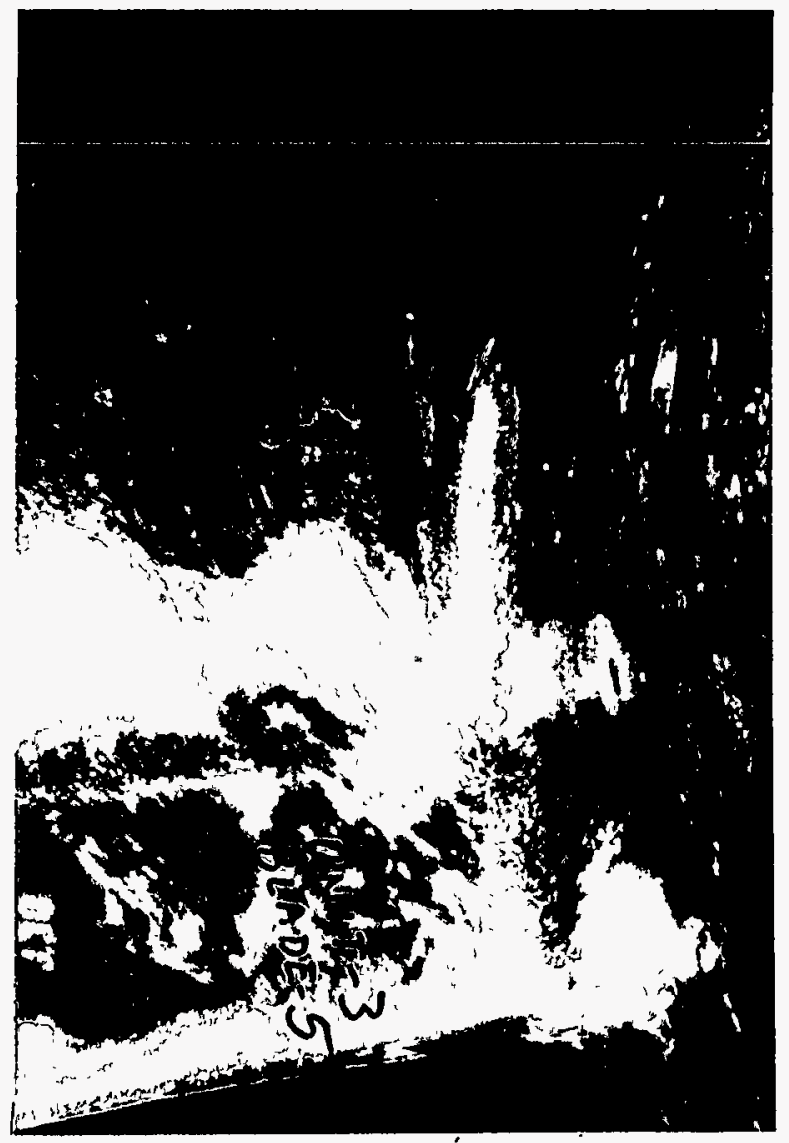

Figure 18. Crown near blade \#5

Cavitation erosion found on blade \#5 after operating a total of 4,871 hours (2,300 hours Generating and 2,571 hours Pumping) between July 5, 1990, and October 5, 1992. The test material was Stoody Hydroloy HQ913. 


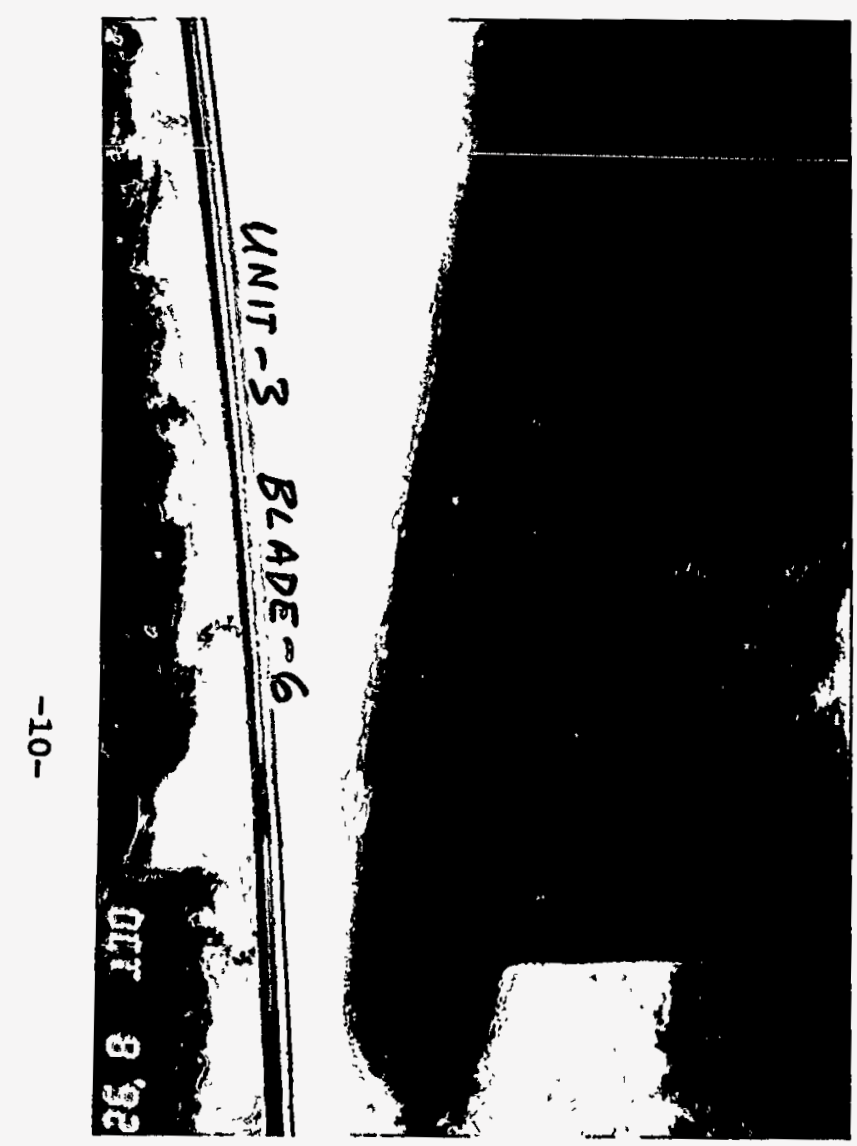

Figure 19. Bottom of blade \#6

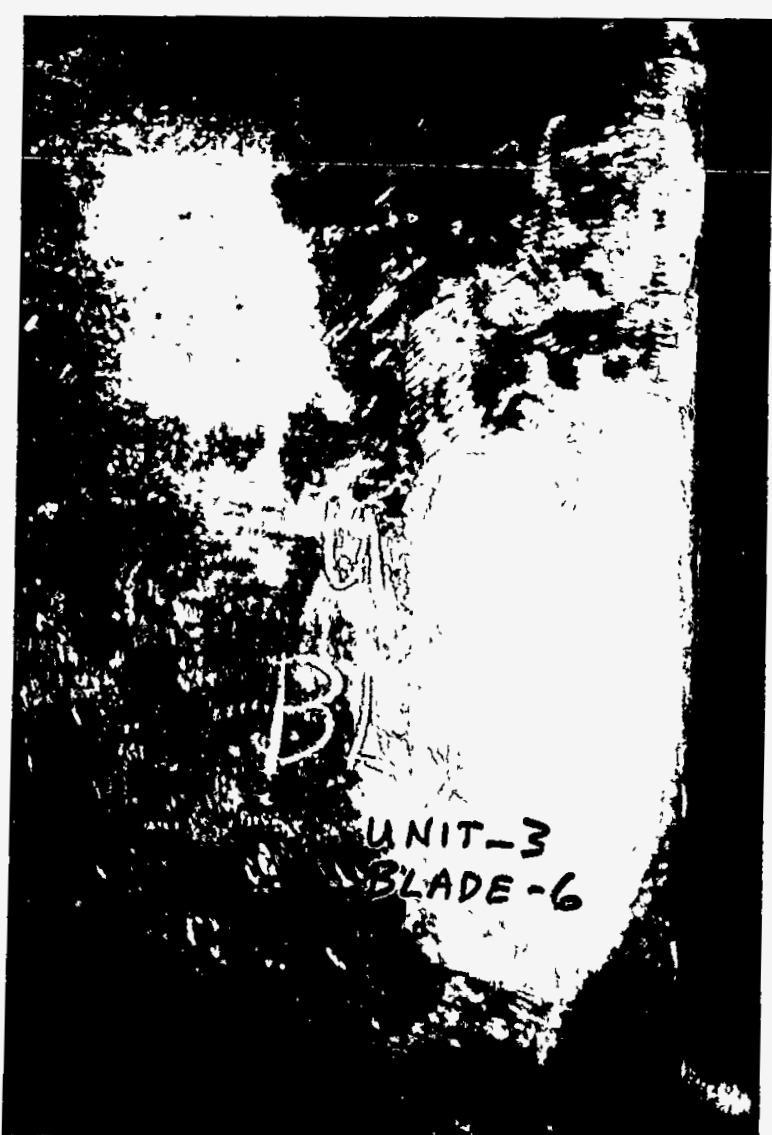

Figure 20. Center of blade $\$ 6$

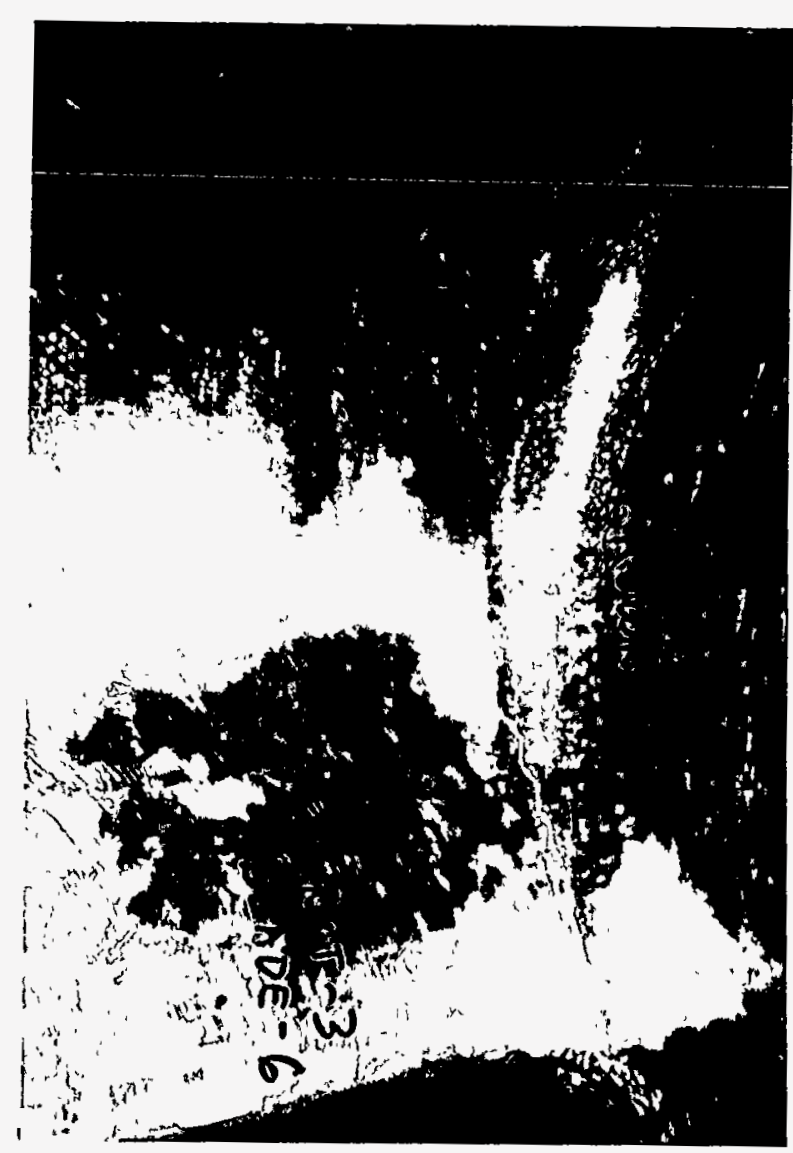

Figure 21. Crown near blade \#6

Cavitation erosion found on blade $\# 6$ after operating a total of 4,871 hours (2,300 hours Generating and 2,300 hours Pumping) between July 5, 1990, and October 5, 1992. The test material was Stoody Hyaroloy HQ913. 


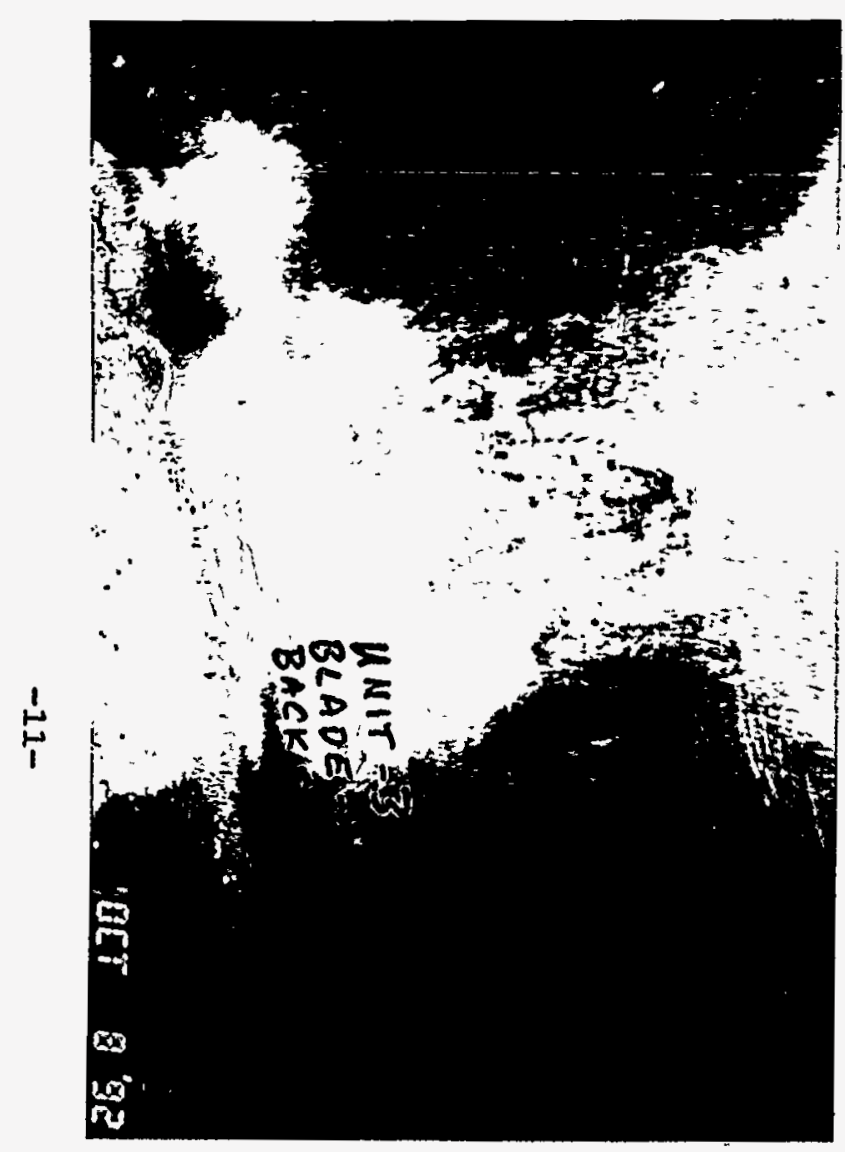

Figure 22. Back side of blade \#1

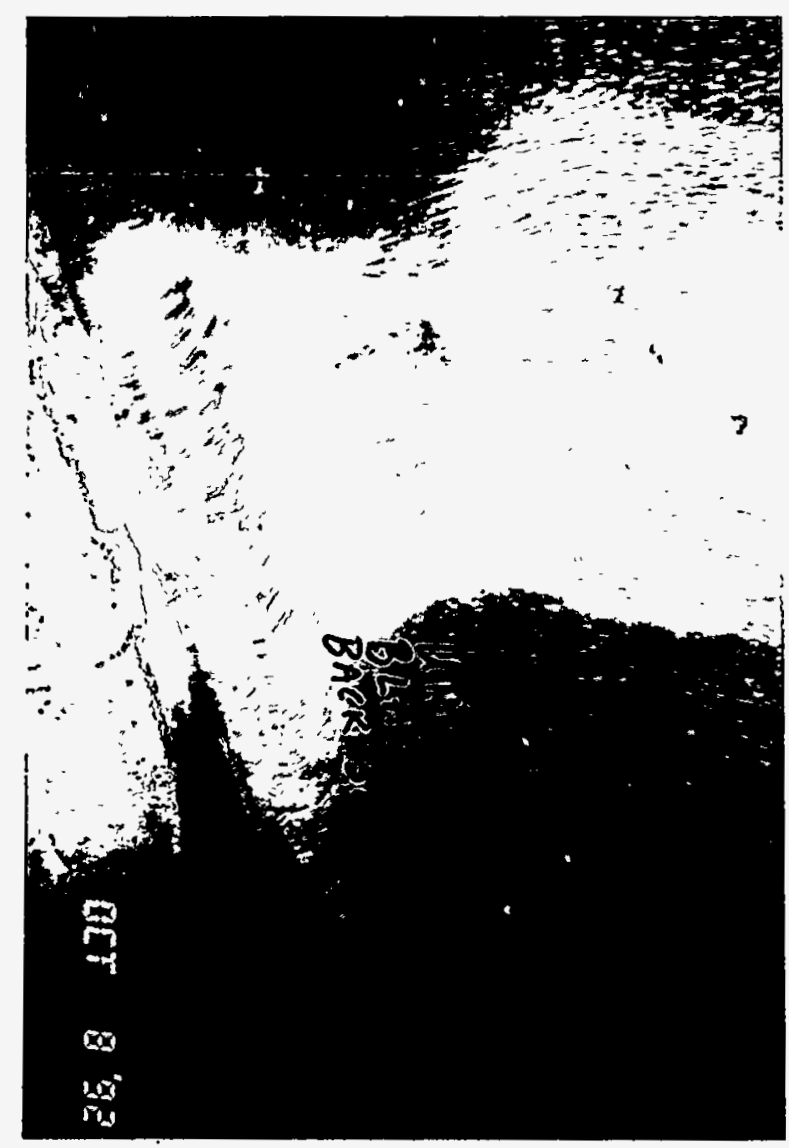

Figure 23. Back side of blade $\$ 2$

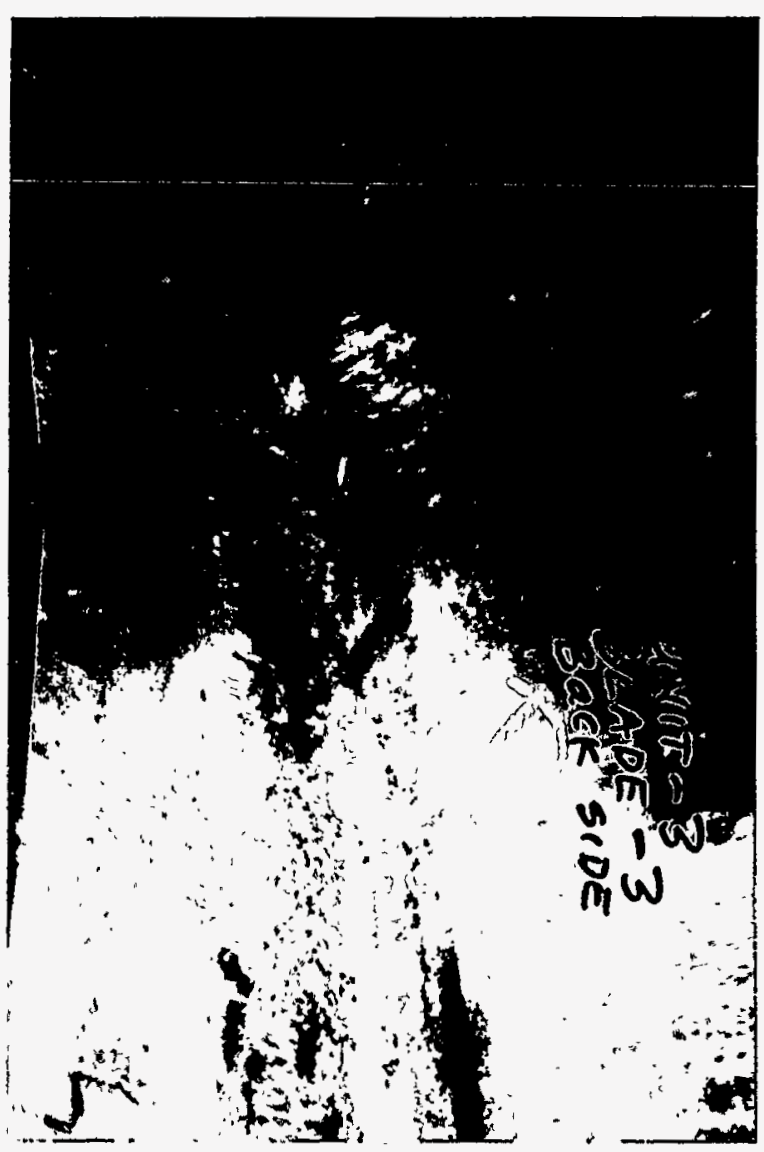

Figure 24. Back side of blade \#3

Cavitation erosion found on the runner after operating a total of 4,871 hours (2,300 hours Generating and 2,571 hours Pumping) between July 5, 1990, and October 5, 1992. The test material was Stoody Hydroloy HQ913. 


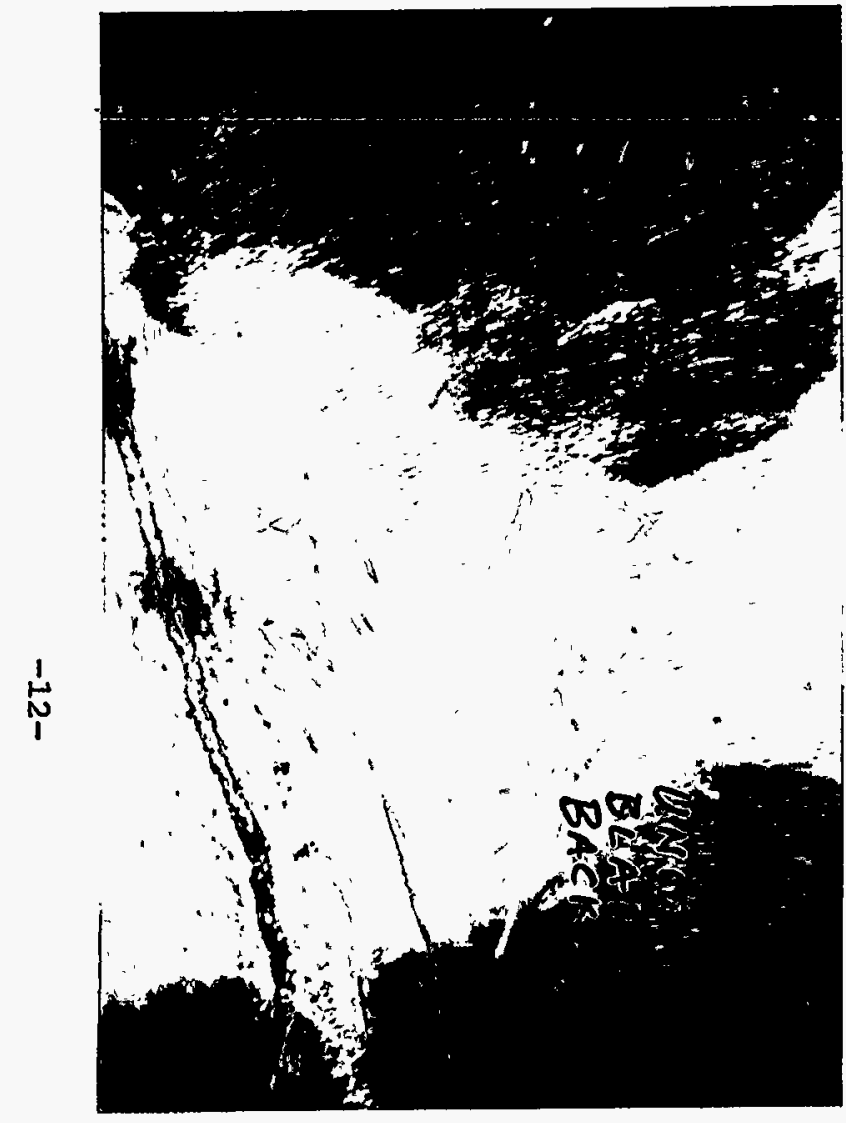

Figure 25. Back side of blade $\# 4$

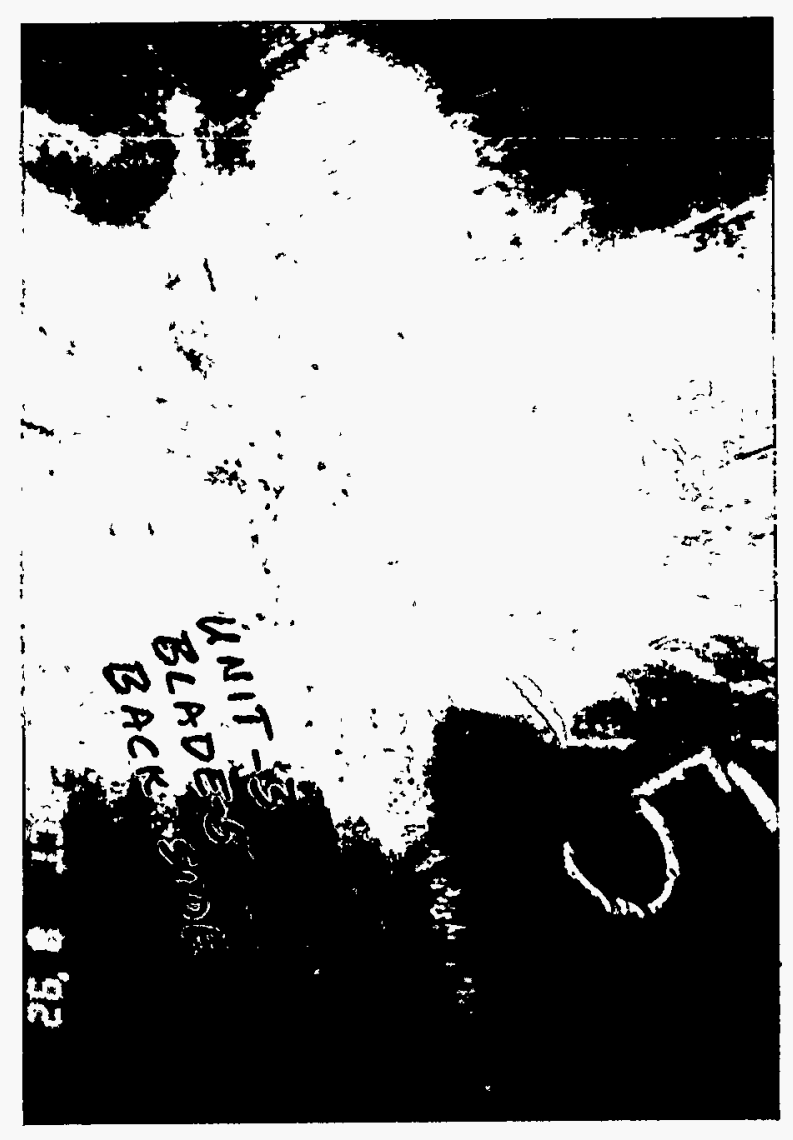

Figure 26. Back side of blade $\# 5$

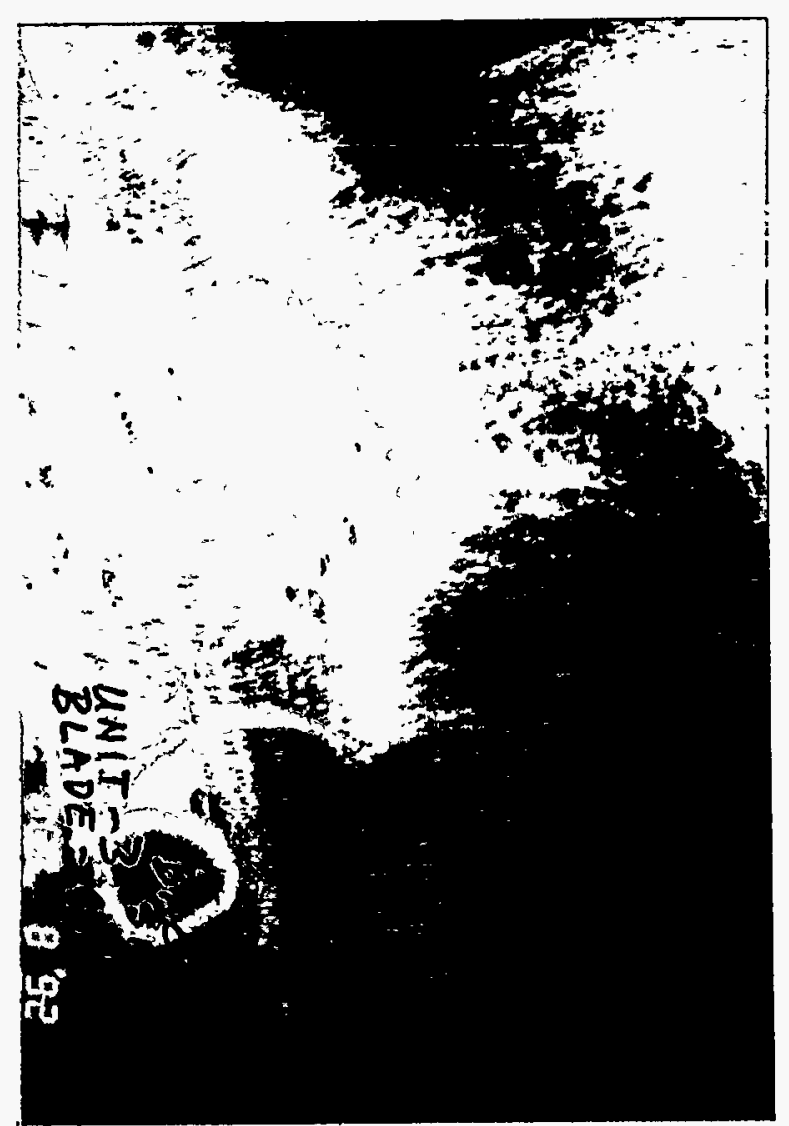

Figure 27. Back side of blade \#6

Cavitation erosion found on the runner after operating a total of 4,871 hours (2,300 hours Generating and 2,571 hours Pumping) between July 5, 1990, and October 5, 1992. The test material was Stoody Hydroloy. HQ913. 


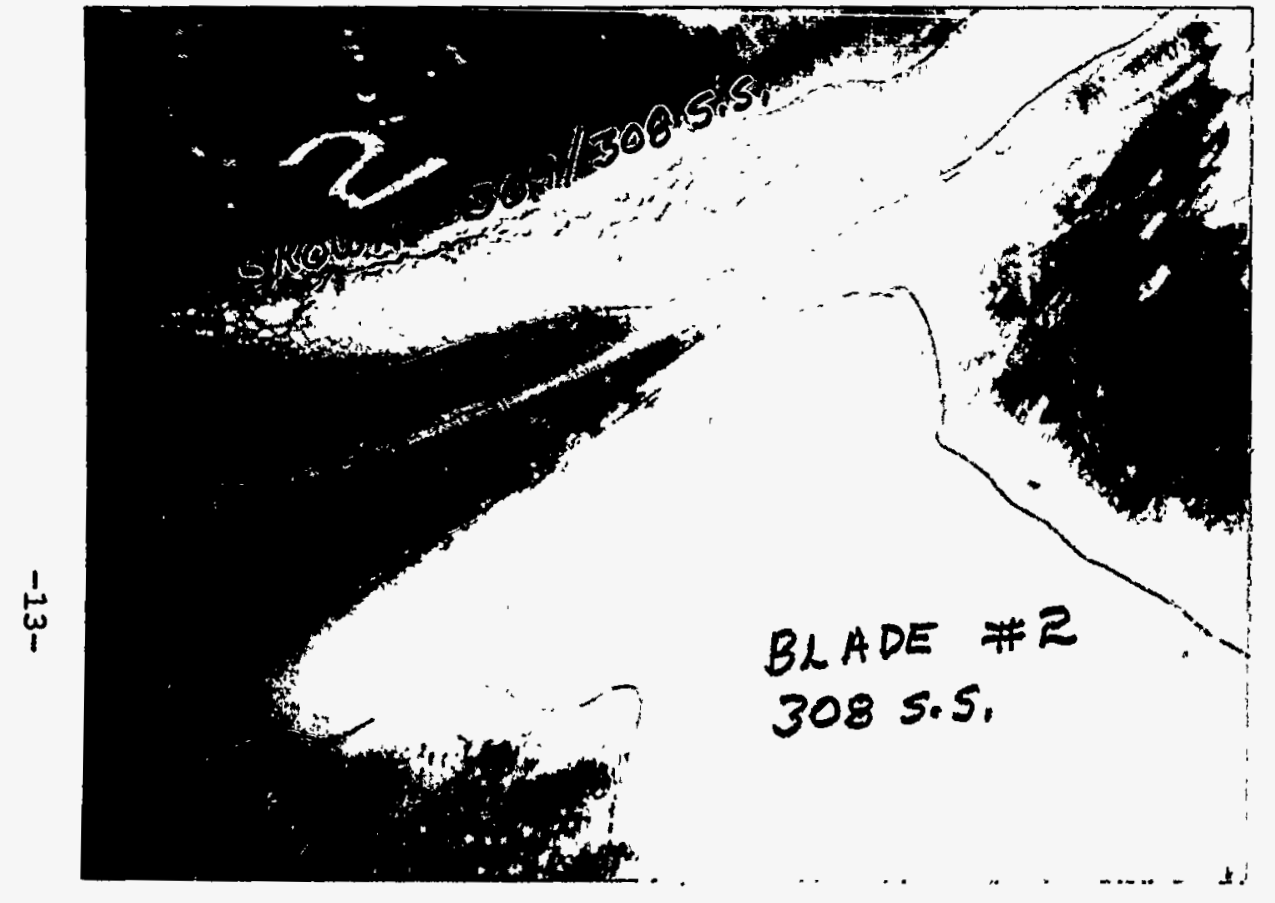

Figure 28 .

Blade \#2 on April 14, 1988, after operating 7,079 hours $(3,429$ hours generating and 3,650 hours pumping). The crown and blade had been repaired with 309 and 308 Stainless Steel electrodes.

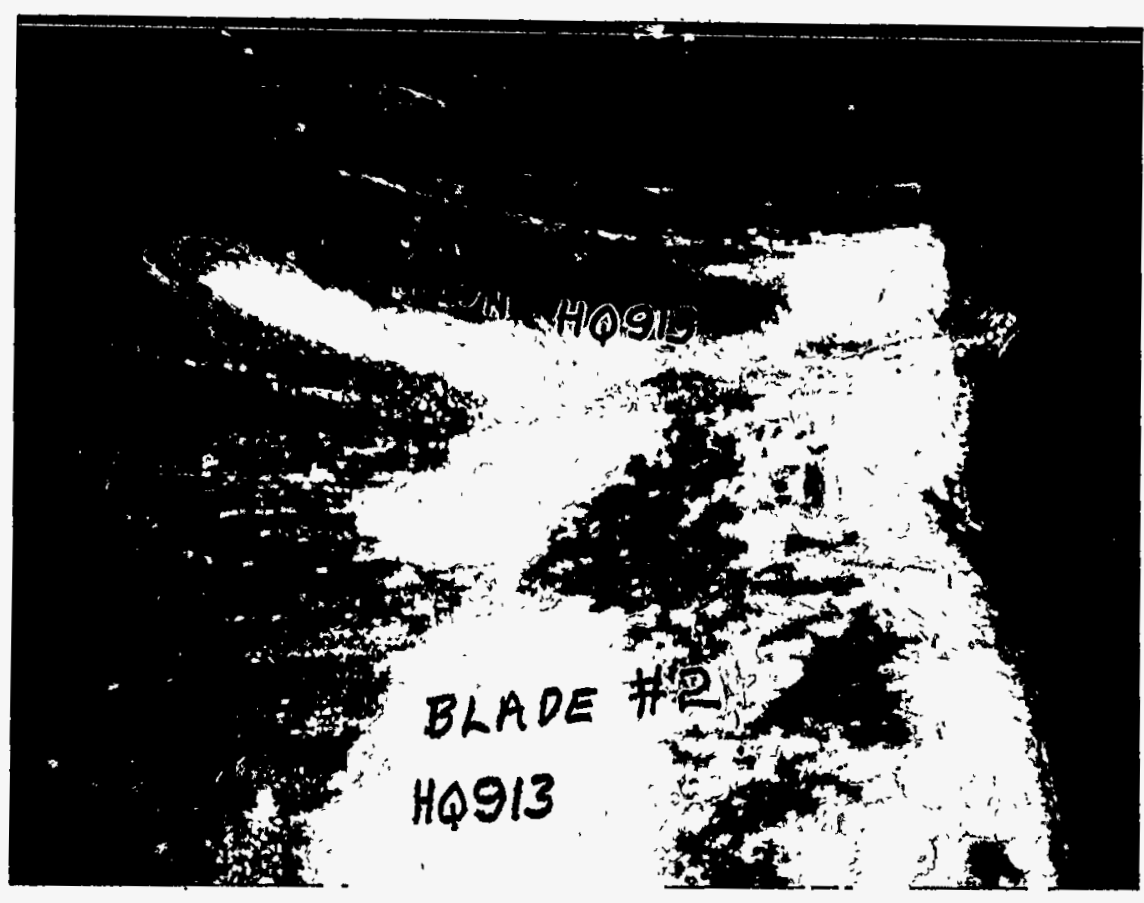

Figure 29.

Blade \#2 on October 8, 1992 , after operating 4,871 hours $(2,300$ hours generating and 2,571 hours pumping) between July 5, 1990 and october 5, 1992. The blades and crown had been repaired with Stoody Hydroloy HQ913 mig wire.

The photographs indicate the cavitation erosion in the crown and on the blade was much more severe when 308 , and 309 Stainless Steel was used to repair the blades than when Stoody Hydroloy Ho913 was used. 


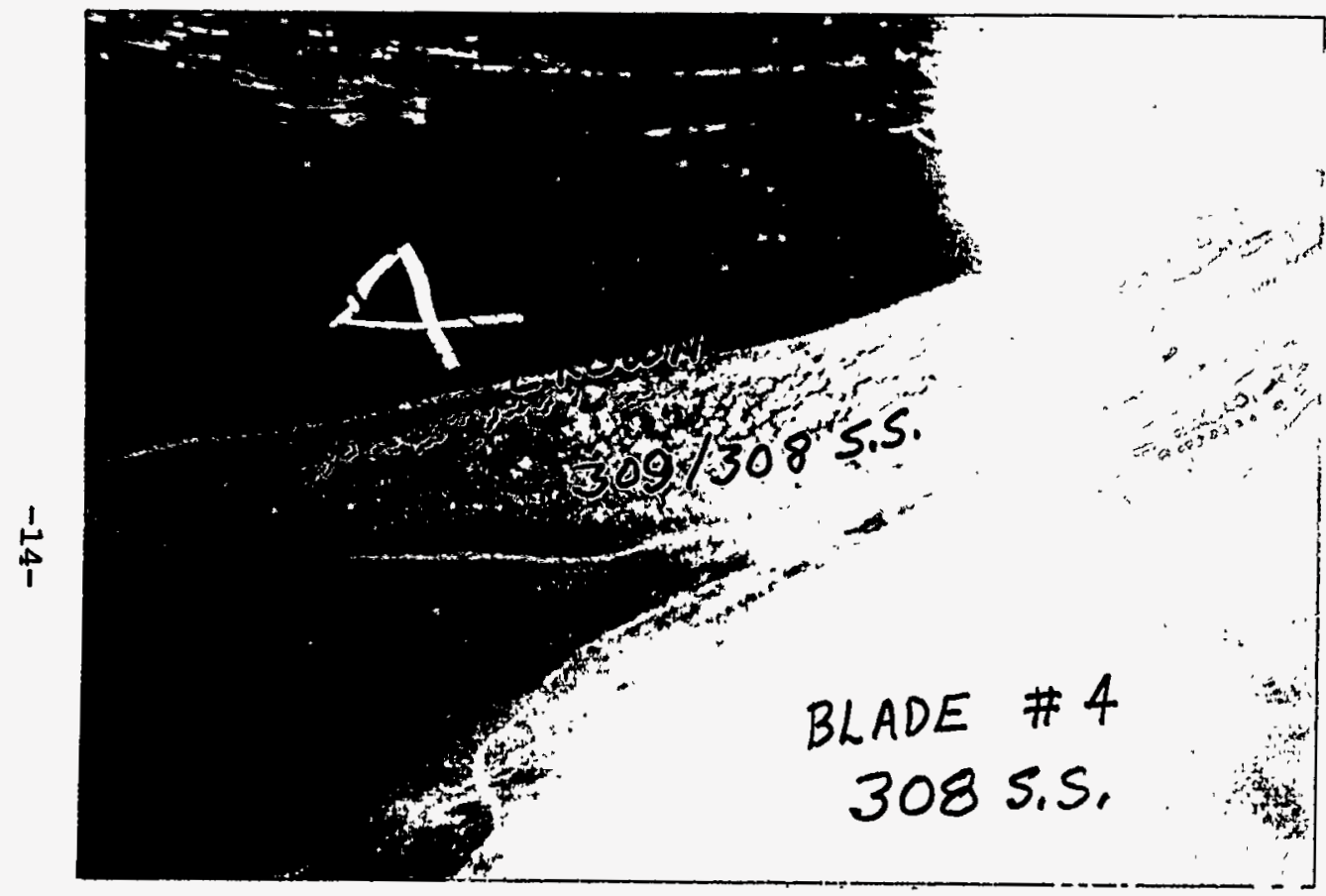

Figure 30.

Blade \#4 on April 14, 1988, after operating 7,079 hours $(3,429$ hours generating and 3,650 hours pumping). The crown and blade had been repaired with 309 and 308 Stainless Steel electrodes.

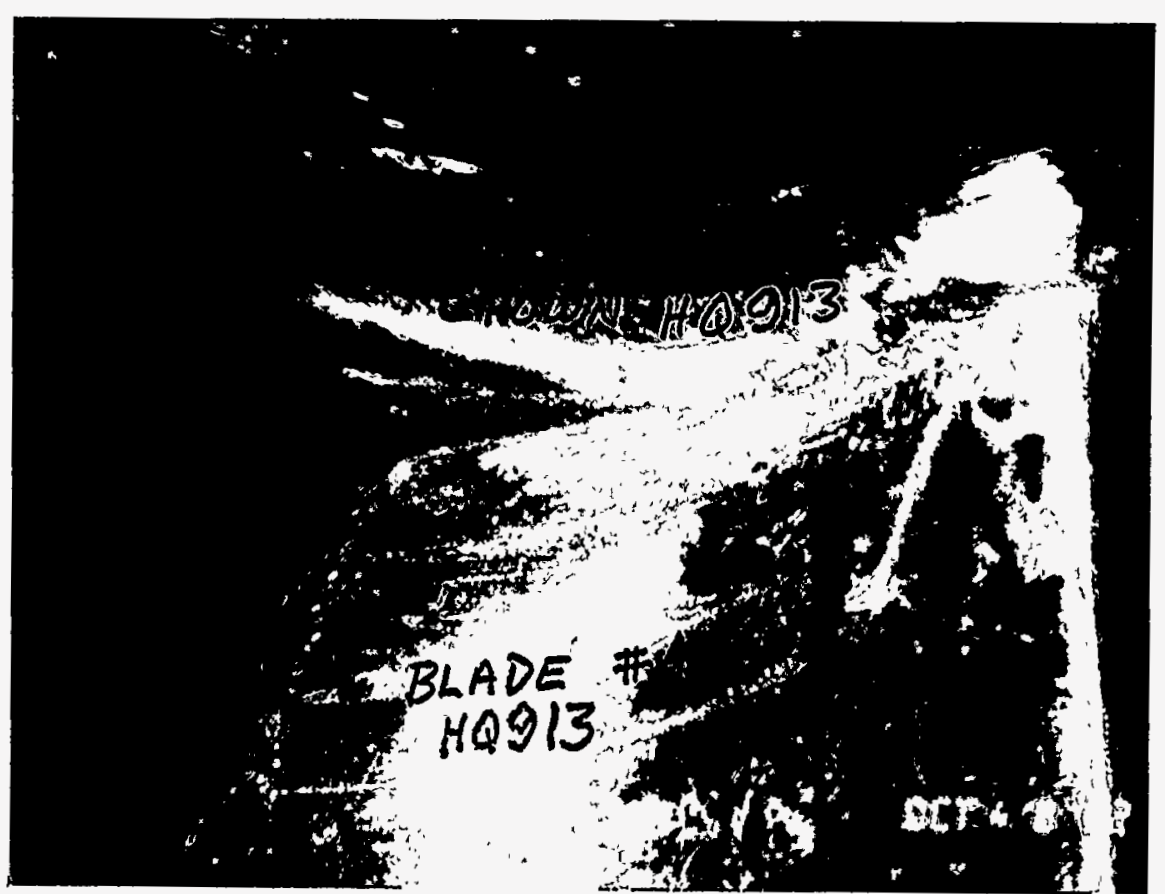

Figure 31.

Blade \#4 on October 8, 1992 , after operating 4,871 hours $(2,300$ hours generating and 2,571 hours pumping) between July 5, 1990 and October 5, 1992. The blades and crown had been repaired with Stoody Hydroloy HQ913 mig wire.

Cavitation erosion in the crown and on the blade was much more severe when 308, and 309 stainless Steel was used to repair the blades than when Stoody Hydroloy HQ913 was used. 